\title{
ENVIRONMENTAL STABILITY STILL IN DANGER, LOOPHOLES OF NEW ENVIRONMENTAL PROTECTION LAW (EPL) IN CHINA
}

\author{
Azra Jabeen*, Huang Xi Sheng ${ }^{* *} \&$ Muhammad Aamir ${ }^{* * *}$
}

Explosive economic and industrial growth in China has led to a significant environmental degradation and it is currently in the process of developing more stringent legal controls. Although new Environmental Protection Law (EPL) 2015, has very important provision like handing out heavier punishment for environmental wrongdoing, specific articles and provisions on tackling pollution, environmental and health monitoring survey and risk assessment mechanism, public participation in environmental protection and encouraging social organizations to initiate public law suits on behalf of citizens. Yet the environmental legal system is still incomplete, and implementation and enforcement of environmental laws have shown major shortcomings. Release of the draft revised EPL has triggered a flood of questions, comments and complaints. Present paper spotlights these very impotent questions and contains a thoughtful discussion about EPL.

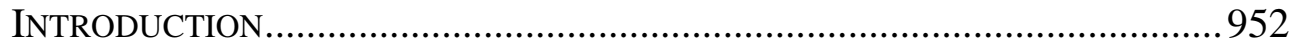

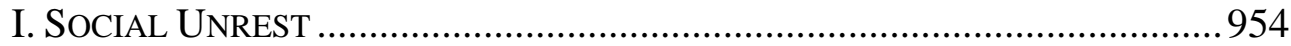

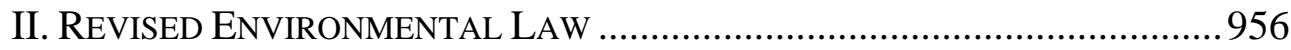

A. Litigation Powers of NGOs ................................................ 958

B. Stiffer Punishments ........................................................... 958

C. Channel for Public Litigation .................................................959

D. Changes of Other Laws .................................................... 960

E. Powerful Tools................................................................ 960

III. POLICY: LOOPHOLES IN CHINA’s NEW ENVIRONMENTAL LAW ..............960

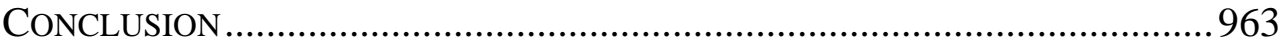

\footnotetext{
* Dr. Azra Jabeen, research fields: Environmental Protection Law, Air Water Pollution Control Laws and Policies. School of Law, Chongqing University, 400044 China.

${ }^{* *}$ Prof. Dr. Huang Xi Sheng, research fields: Environmental Protection Law, Air Water Pollution Control Laws and Policies, Economics Laws and Policies. School of Law, Chongqing University, 400044 China.

${ }^{* * *}$ Asst. Prof. Dr. Muhammad Aamir, research field: Material Science and Engineering. Key Laboratories of Low-grade Energy Utilization Technologies and Systems, Chongqing University, Chongqing, 400044 China.
} 


\section{INTRODUCTION}

Economic reform brought revolutionary changes to China ${ }^{1,2}$ including raising living standard of hundreds of millions of Chinese people and makes china as the No. 2 economy of the world ${ }^{3}$. However, the excessive use of $\mathrm{coal}^{4}$ for the expansion of heavy industry and urbanization creates numerous environmental problems. A report issued in April, 2014 showed that, nearly 60 percent of monitored areas in China had "very poor" or "relatively poor" underground water quality in $2013^{5}$. The Ministry of Environmental Protection and the Ministry of Land and Resources joint report on April 17, 2014 showed that, about 16.1 percent of the country's soil is polluted ${ }^{6}$. China has many environmental issues, severely affecting its biophysical environment as well as human health. The water resources of China are affected by both severe water quantity shortages and severe water quality pollution. The population burden and rapid economic growth as well as slack environmental oversight have increased water demand and pollution. China has responded by measures such as rapidly building out the water infrastructure such as South-North Water Diversion Project ${ }^{7}$ and increased regulation as well as exploring a number of further technological solutions. South-North Water Diversion Project also has population displacement, health and environmental costs. Water usage by its coal-fired power stations is drying-up Northern China, ${ }^{8,10}$. Desertification remains a serious problem,

\footnotetext{
${ }^{1}$ Elizabeth C. Economy, The River Runs Black: The Environmental Challenge to China's Future 368 (Ithaca: Cornell University Press 2004); KrIsten A. DAY, ChINA's ENVIRONMENT AND the Challenge of Sustainable Development 293 (Kristen A. Day ed., New York: M.E. Sharpe 2005).

${ }^{2}$ Kahn J. \& Yardley J., China is Struggling to Rein in Pollution; Nation Falling Victim to Its Own Progress, The New YoRK Times, Aug. 26, 2007.

${ }^{3}$ T. N. Srinivasan, China, India and the World Economy 2, STAN. CTR, FOR InT'L Dev., Working PAPER No. 286, 2006. Available at http://scid.stanford.edu/pdf/SCID286.pdf.

${ }^{4}$ Kahn \& Yardley, (Part I, supra note 2) "there is little question that growth came at the expense of the country's air, land and water".

${ }^{5}$ Mu Xuequan, Transitioning China Needs Tougher Environmental Law (Beijing: Xinhua, April 25, 2014). Available at http://news.xinhuanet.com/english/china/2014-04/25/c_126431782.htm. ${ }^{6}$ Ministry of Environmental Protection, The People's Republic of China, China's Legislature Adopts Revised Environmental Law, Media News, Beijing, Apr. 24, 2014. Available at http://english.mep.gov.cn. News and Media Service Media News.

${ }^{7}$ Daniel Carpenter-Gold, Promises and Pitfalls in China's New Environmental Protection Law, (September 14, 2014). Available at http://www3.law.harvard.edu/.../promises-and-pitfalls-in-c....

${ }^{8}$ Business Week, On China's Electricity Grid, East Needs West-for Coal, Business WeEK Mar. 21, 2013.

${ }^{9}$ Business Week, Chinese Utilities Face \$20 Billion Costs Due to Water, BusinEss WeEK, Mar. 24, 2013.

${ }^{10}$ Han Jun, Effect of Integrated Ecosystem Management on Land Degradation Control and Poverty Reduction, Workshop on Environment, Resources and Agricultural Policies in China (June 19, 2006). Retrieved March 26, 2008.
} 


\section{ENVIRONMENTAL STABILITY STILL IN DANGER953}

is expanding at a rate of more than $67 \mathrm{~km}^{2}$ every year. 90\% of China's desertification occurs in the west of the country ${ }^{11}$. Industrial pollution is causing widespread environmental and health problems. World's twenty most polluted cities are found in China ${ }^{12,13}$. An official report released in 2014 , found that, $20 \%$ of the country's farmland, and $16 \%$ of its soil overall, is polluted. An estimated $60 \%$ of the groundwater is polluted ${ }^{14}$. According to a report on April 11, 2014, more than 2.4 million people in Lanzhou, northwest China's Gansu Province, were affected by tap water that contained excessive levels of benzene ${ }^{15}$. Although China met the basic emission target in 2013, but the challenges of water, air and soil quality remain serious. To curb the air pollution problem, the Chinese government announced a five-year, US\$277 billion plan in 2013. Northern China will receive particular attention, as the government aims to reduce 25 percent air emissions by 2017, compared with 2012 levels $^{16}$.

Environmental policy in China is set by the National People's Congress and managed by the Ministry of Environmental Protection. In Chinese environmental policy, the central government issues fairly strict regulations, but the actual monitoring and enforcement is largely undertaken by local governments that are more interested in economic growth. Effective implementation of laws, clarification, national and provincial government roles and strengthen the legal system is a tough job for Chinese officials ${ }^{17}$.

The environmental protection awareness work of non-governmental forces, such as lawyers, journalists, and non-governmental organizations, is limited by government regulations ${ }^{18}$. In response to public pressure, the national government has undertaken a number of measures to curb pollution in China and improve the country's environmental situation ${ }^{19}$. However, the

\footnotetext{
${ }^{11}$ Edward Wong, Cost of Environmental Damage in China Growing Rapidly Amid Industrialization, THE NeW YoRK Times, Mar. 29, 2013. Retrieved March 30, 2013.

${ }^{12}$ Air Pollution Grows in Tandem with China's Economy, NPR, Mar. 17, 2007. Retrieved January 21, 2013. Available at http://www.npr.org/templates/story/story.php?storyId=10221268.

${ }^{13}$ The Most Polluted Places on Earth, CBS NEws, Jan. 8, 2010. Retrieved January 21, 2013.

${ }^{14}$ China's Eco-crisis: 60\% of Groundwater Polluted, THE JAPAN TIMES, Apr. 24, 2014. Available at http://www.japantimes.co.jp/.../chinas-eco-crisis-60-groundwater.

${ }^{15}$ EXCESSive BENZENE Found In NW ChinA’s WATER (Lanchou: Xinhua, April 11, 2014). Available at http://news.xinhuanet.com/english/china/2014-04/11/c_133255669.htm.

${ }^{16}$ Jennifer Duggan, China's Polluters to Face Large Fines under Law Change, THE GuARDian, Apr. 25, 2014. Retrieved April 27, 2014.

${ }^{17}$ EPA, China Environmental Law Initiative Home, (updated August 22, 2013) Available at http://http://www.epa.gov/ogc/china initiative_home.htm.

${ }^{18}$ Melanie Hart \& Jeffrey Cavanagh, Environmental Standards Give the United States an Edge over China, (Center for American Progress: April 20, 2012). Retrieved July 28, 2013.

${ }^{19}$ Louisa Lim, Air Pollution Grows in Tandem with China's Economy, NPR, May 17, 2007.

Retrieved September 8, 2013.
} 
government's response has been criticized as inadequate ${ }^{20}$. Encouraged by national policy that judges regions solely by their economic development; corrupt and unwilling local authorities have hampered enforcement of environmental laws and policies in their respective regions ${ }^{21}$. Nonetheless, in April of 2014, the government amended its environmental law to better fight pollution ${ }^{22}$. Environmental policies implementation as well as environmental laws enforcement is done by The Ministry of Environmental Protection (MEP) $)^{23}$. The Ministry is responsible for water, air and land protection from pollution and contamination in China. State Council directly empowered MEP to implement environmental policies and enforce environmental laws and regulations. Complementing its regulatory role, it funds and organizes research and development. In 1983, the Chinese government announced that, environmental protection would become a state policy.

\section{SOCIAL UNREST}

In recent years, China faced increasing number of mass protests over environmental issues, which are steadily grown day by day. Residents from few cities com out to the streets against different projects which they believe are a major threat to the environment and public health. In many cases, the projects were later suspended. From 2001 to 2005, Chinese environmental authorities received more than 2.53 million letters and 430,000 visits by 597,000 petitioners seeking environmental redress ${ }^{24,25}$. From 2001 to 2007, mass protests over environmental issues gradually increased ${ }^{26}$. The increased public attention on environmental matters pressurized the Chinese government to display serious attitude towards environmental issues. Stricter environmental regulations were subsequently implemented. Subsidies for some polluting industries were cancelled, while other

\footnotetext{
${ }^{20}$ Richard Silk, China Weighs Environmental Costs; Beijing Tries to Emphasize Cleaner Industry over Unbridled Growth after Signs Mount of Damage Done, (Beijing: July 23, 2013).

${ }^{21}$ Joseph Kahn \& Jim Yardley, As China Roars, Pollution Reaches Deadly Extremes, THE NEw YoRK TimEs, Aug. 26, 2007. Retrieved July 28, 2013.

${ }^{22}$ Rebecca Valli, China Revises Environmental Law, VoICE OF AMERICA, Apr. 25, 2014. Retrieved April 27, 2014. Available at http://www.voanews.com/.../china-revises-environmental-law.

${ }^{23}$ Jianmin Hua, Zujian Huanjingbaohubu Jiada Huanjing Baohulidu (in Mandarin Chinese), (March 11, 2008). Available at http://News.sina.com.cn. Retrieved February 12, 2013.

${ }^{24}$ Alex Wang, Environmental Protection in China: The Role of Law, ChinA Dialogue. Retrieved February 12, 2013.

${ }^{25}$ Ma Jun, How Participation Can Help China’s Ailing Environment, China DiALOGUE (January 31, 2007). Retrieved July 28, 2013.

${ }^{26}$ Environmental Activists Detained in Hangzhou, Human Rights IN CHINA (October 25, 2012).

Retrieved July 28, 2013.
} 


\section{ENVIRONMENTAL STABILITY STILL IN DANGER955}

polluting industries were shut down. However, many internal environmental targets were missed ${ }^{27}$. After 2007, local authorities do not care about the effectiveness of central decisions, so influence of corruption was a hindrance to effective enforcement. In 2008, the State Environmental Protection Administration (SEPA) was officially replaced by the Ministry of Environmental Protection (MEP) during the March National People's Congress sessions in Beijing ${ }^{28}$. Citizen awareness increased in 2010 regarding government decisions that are perceived as damaging environment ${ }^{29}$. In April 2012, protests occurred in the southern town of Yinggehai following the announcement of a power plant project. Again in October 2012, police clashed with protester, leading to 50 arrests and almost 100 injuries $^{30}$. A protest occurred by hundreds of thousands demonstrators in Qidong city in response to a waste pipeline for a paper factory in July 2012. In total, more than 50,000 environmental protests occurred in China during $2012^{31}$. By early 2013, public protests had succeeded in consistently gaining concessions from local governments, and in March 2013, Li Keqiang, China's premier, promised that his government will try to overcome on the pollution crises in China ${ }^{32}$.

According to the U.S. Environmental Protection Agency, China has shown great determination to "develop, implement, and enforce a solid environmental law framework". However, the impact of such efforts is not yet clears ${ }^{33}$. Country's top national priority is the harmonization between the Chinese society and the natural environmental system ${ }^{34,35}$.

\footnotetext{
${ }^{27}$ Richard Silk, China Weighs Environmental Costs; Beijing Tries to Emphasize Cleaner Industry over Unbridled Growth after Signs Mount of Damage Done, (Beijing: July 23, 2013).

${ }^{28}$ Jianmin Hua, Zujian Huanjingbaohubu Jiada Huanjing Baohulidu (in Mandarin Chinese), (March 11, 2008). Available at http://News.sina.com.cn. Retrieved February 12, 2013.

${ }^{29}$ Keith Bradsher, Bolder Protests against Pollution Win Project's Defeat in China, THE NEW YorK Times, Jul. 4, 2012. Retrieved July 5, 2012.

${ }^{30}$ Chinese Protesters Clash with Police over Power Plant, THE GuARDIAn (October 22, 2012). Retrieved July 28, 2013.

${ }^{31}$ John Upton, China to Spend Big to Clean up Its Air, Grist MaGAzINE (Grist.org. Inc., July 25, 2013). Retrieved July 27, 2013.

${ }^{32}$ Benjamin Kang Lim \& Sui-Lee Wee, Something in the Air, (Beijing, China: March 17, 2013). Available at http://www.reuters.com/article/2013/03/17/china-parliament-environment idUSL3NoC903K20130317 (last visited October 7, 2013).

${ }^{33}$ EPA, China Environmental Law Initiative, (August 21, 2013). Available at http://www.epa.gov/ogc/china/initiative_home.htm.

${ }^{34}$ Wang Alex, The Search for Sustainable Legitimacy: Environmental Law and Bureaucracy in China, 37 HARVARD ENVIRONMENTAL LAW REVIEW 365 (2013).

${ }^{35}$ NRDC, Environmental Law in China.
} 


\section{REVISED ENVIRONMENTAL LAW}

During the opening session of the National People's Congress in March 2014, president Xi Jinping declared "war" on pollution. After long debate of two years, the parliament approved a new law in April 2014, which came into effect in 2015. It has 70 provisions, compared to the 47 of the existing law ${ }^{36}$. More than 300 different groups will be able to sue on the behalf of people harmed by pollution ${ }^{37}$. The new Environmental Protection Law (EPL) has greatly strengthened the country's environmental law regime. The new law empowers environmental enforcement agencies to enforce strict penalties and seize property of illegal polluters, defines areas which require extra protection, and gives independent environmental groups more ability to operate in the country ${ }^{38}$. This kind of right is added first time in environmental law history of China. The new articles of the law specifically address air pollution, and call for additional government oversight ${ }^{39}$. Environmental bureaus can confiscate polluting equipment, and detained the company bosses for up to 15 days if they fail to submit environmental impact assessments or refuse to comply with orders to suspend production under the current draft ${ }^{40}$. In the past, environmental authorities could only give small and toothless fines to deter businesses from illegally discharging pollution. Under the new law, however, they will be able to fine companies on a daily basis (rather than having to keep to an overall limit). Local governments will be answerable for failing to enforce environmental laws. The economic progress of the Regions will be judged entirely under environmental protection in newly amended law. New law makes local governments responsible to awaken the environmental protection awareness in the citizen. Article 6 of new law encouraged individuals to "adopt a lowcarbon and frugal lifestyle and perform environmental protection duties" such as recycling their garbage under the law ${ }^{41}$. A number of different classes of protected areas are recognized under new Chinese Environmental

\footnotetext{
${ }^{36}$ Jennifer Duggan, China's Polluters to Face Large Fines under Law Change, THE GUARDIAN (April 25, 2014). Retrieved April 27, 2014.

${ }^{37}$ Joseph Kahn \& Jim Yardley, As China Roars, Pollution Reaches Deadly Extremes, THE NEW YorK TiMES, Aug. 26, 2007. Retrieved July 28, 2013.

${ }^{38}$ Joseph Kahn \& Jim Yardley, As China Roars, Pollution Reaches Deadly Extremes, THE New YoRK Times, Aug. 26, 2007. Retrieved July 28, 2013.

39 Jennifer Duggan, China’s polluters to Face Large Fines under Law Change, THE GuARDIAN (April 25, 2014). Retrieved April 27, 2014.

${ }^{40}$ Richard Pullin, RPT-China's New Environment Law Submitted to Parliament, (Xinhua, April 22, 2014) Available at http://www.reuters.com/.../china-environment-idUSL3NONE0TC20140422.

${ }^{41}$ Jennifer Duggan, China’s polluters to Face Large Fines under Law Change, THE GUARDIAN (April 25, 2014). Retrieved April 27, 2014.
} 


\section{ENVIRONMENTAL STABILITY STILL IN DANGER957}

law. National, provincial and local governments all have the power to designate areas as protected. Regardless of designation, most enforcement is made at the local level.

Highlighting the importance of the legislation in the country's pursuit of sustainable development, The amendment process in 1989 law was started in 2001, and the draft updates went through three fruitless readings that was rare in China for a law or amendment to go through three readings and not be passed, before 23rd April, 2014 fourth and final round. At each stage, the proposed changes proved controversial.

Of the hotly contested points, the clause setting the rules for environmental public interest litigation ${ }^{42}$ attracted most attention. In the second draft, the government-backed All-China Environmental Federation was given sole right to bring environmental public interest lawsuits, prompting public discontent. Later, in the third draft, this right was extended to national level organizations. However, the changes again failed to convince the public.

The updated law lays the foundations for future public interest litigation in China's environmental sphere, and adds legal weight to the public campaign against pollution. Effective implementation of newlyamended environmental protection law will make a significant difference ${ }^{43}$. Article 4 of the new law says that, economic and social development should be coordinated with environmental protection; Article 39 of updated law encourages studies on the environmental quality impact on public health, urging prevention and control of pollution-related diseases. It says that, the country should establish and improve an environmental and health monitoring survey and risk assessment mechanism ${ }^{44}$. Updated law has specific articles and provisions to control the smog pollution, citizen's environmental protection awareness and whistleblowers ${ }^{45}$.

Lack of powerful law, weak implementation and irresponsible and non serious attitude of officials toward environmental pollution are the causes of China's deteriorating environment.

\footnotetext{
${ }^{42}$ Liu Jiangqiang, China's New Environmental Law Looks Good on Paper' China, DialoGUE (Beijing: April 24, 2014). Available at https://www.chinadialogue.net/...new-environmentallaw...good.../en.

${ }^{43}$ Liu Jiangqiang, China's New Environmental Law Looks Good on Paper' China, DialoguE (Beijing: April 24, 2014). Available at https://www.chinadialogue.net/...new-environmentallaw...good.../en.

${ }^{44}$ Environmental Protection Law of the People's Republic of China, (April 24, 2014).

${ }^{45}$ Wang, NPC Adopts Revised Environmental Protection Law, (Xinhua, April 24, 2014). Available at http://english.cri.cn/6909/2014/04/24/2361s823675.htm.
} 


\section{A. Litigation Powers of NGOs}

It is the first time the environmental protection law has been revised since 1989.

The revised Environmental Protection Law allows qualified NGOs to take legal action in environmental matters of public interest. It is a relatively recent phenomenon that, NGOs can contribute to putting more pressure on local governments to help them implement the law ${ }^{46}$. If the provision is officially confirmed by the National People's Congress, the ability of Chinese NGOs to bring environmental suits on behalf of the public will be far broader than in any previous versions.

The role of NGOs as prosecution in public interest cases is also significant because they can obtain injunctive relief, unlike other plaintiffs in environmental cases. Almost 300 NGOs empowered by the revised law. Environmental organizations registered with a civil affairs bureau at municipal level or above, which have been operating for at least five years, can initiate public interest litigation (Article 58). Litigation powers of Chinese NGOs were recognized in 2012 by the amended Civil Procedure Law, which allowed "related organizations" to sue polluters, but courts often refuse to accept suits filed by NGOs because the provisions were vague. Specifying the requirements for NGOs to sue is one the more significant revisions in the new law.

\section{B. Stiffer Punishments}

New updated law detained the polluters for 15 days if their enterprises harm the environmental impact assessments, refuse to suspend banned production, fail to obtain a pollutant discharge permit but discharge pollutants and refuse to suspend the discharge after administrative bodies issue a ban; or if they neglect supervision through means including copying monitoring data or improperly operating pollution prevention equipment. The length of detention would depend on the impact of their violations. Responsible persons would face the same punishments if their enterprises produce or use forbidden pesticides and refuse to make corrections. The law also proposes that, organizations in charge of environmental impact assessments and supervision would bear joint liabilities if they are found to have acted fraudulently. If local officials are guilty of unacceptable crime, environmental related wrongdoing, falsifying data or compel others to copy

\footnotetext{
${ }^{46}$ Lican Liu, Environmental NGO Leader, A Conversation with Chinese Fellow, Environmental NGO Leader, In THE NEWS, Sep. 17, 2014.
} 


\section{ENVIRONMENTAL STABILITY STILL IN DANGER959}

data dishonestly, failing to make public according to law by publicizing environmental information, or failing to give closure orders to enterprises which illegally discharge pollutants may be dismissed or give an opportunity to improve. If offenders' behaviors constitute crimes, they will be held criminally responsible. The law says a daily-based fine system will be introduced to punish offenders. An enterprise will face daily fine if it illegally discharge pollutants and refuse to the authorities to correct its wrongdoing. In the past, enterprises received a one-off fine, that are out in new law; daily penalties (Art. 59), confiscation of equipment (Art. 25), and even jail time for "the person directly in charge" of the polluting entity (Art. 63) are in. The groundwork has been laid for a comprehensive emissions permitting system (Art. 45). Regions which fail to meet environmental targets designated by the central government will face blanket suspensions of the right to undertake new construction projects (Art. 44) ${ }^{47}$. The new penalty system calls on local environmental protection bureaus to issue corrective orders and fines to violators and, beginning the day after the corrective order is issued, collect a fine for each day the violation continues, based on the original penalty amount. Local governments may strengthen these daily penalty provisions by enlarging the types of violations that are subject to continuous daily fines. Standing to bring public interest litigation will be extended to social groups that are registered with the Civil Affairs Agencies of Municipal People's Governments (with jurisdiction of districts) or above generally mean the governments at prefecture (municipal) and above levels, including municipal (prefecture), provincial and central governments). The amendments will give China's Ministry of Environmental Protection (MEP) greater legal authority to regulate and penalize polluters. The new amendments include provisions on transparency, such as requirements for real-time pollution data monitoring, and criminal penalties for those who evade such monitoring systems. They also encourage studies on the impact of environmental pollution on public health and urge the prevention and control of pollution-related diseases. The amendments encourage civic action in environmental pollution by setting protections for whistleblowers and declaring June 5 as Environment Day.

\section{Channel for Public Litigation}

The new law allows public interest litigation on environmental issues. Public interest litigation might also help cool the mass protests which are

\footnotetext{
${ }^{47}$ Daniel Carpenter, Promises and Pitfalls in China's New Environmental Protection Law, HARVARD ENVIRONMENTAL LAW REVIEW (September 14, 2014).
} 
the result of environmental pollution have been increasing in recent years. According to the new law, social organizations which have been engaged in public litigation on environmental issues for more than five years, should not seek to profit through such litigation, Courts should receive public litigation on environmental issues according to the new draft. By promoting public interest litigation, it is hoped that, the public's appeal for a better environment can be addressed through rule of law, instead of resorting to protests. Finally, a number of new avenues for public participation have been opened up (Arts. 53-58).

\section{Changes of Other Laws}

China has more than 30 environment-related laws and about 90 administrative regulations concerning environmental protection. After the adoption of the revised Environmental Protection Law, the country's fundamental environment law, other environmental laws may also face changes. According to the NPC Standing Committee's annual legislation plan, the air pollution prevention and control law will be revised.

\section{E. Powerful Tools}

There were more than 20 new articles added to the original law of $1989^{48}$. The new law has set up powerful mechanisms for enforcement, combining strengthened hard mechanisms legally binding environmental protection responsibilities and consequences for environmental violations with soft mechanisms of public channels for participation in environmental protection. The updated law has provided a powerful tool for authorities to take stronger punitive actions against pollution and ensure that, information on environmental monitoring and impact assessments is made public. But the real challenge lies in ensuring that, the new law is implemented in full and in a consistent manner ${ }^{49}$.

\section{POLICY: LOOPHOLES IN CHINA’s NEW ENVIRONMENTAL LAW}

China's Environmental Protection Law (EPL) is the main national environmental legislative framework. Yet the environmental legal system is incomplete, and implementation and enforcement of environmental laws

\footnotetext{
${ }^{48}$ Environmental Protection Law of the People's Republic of China', (Adopted on December 26, 1989).

${ }^{49}$ Ren Zhongxi, Transitioning China Needs Tougher Environmental Law, (Xinhua, April 25, 2014). Available at http://www.chinadaily.com.cn/china/2014-04/.../content_17442588.htm.
} 


\section{ENVIRONMENTAL STABILITY STILL IN DANGER961}

have shown major shortcomings ${ }^{50,51}$. A controversial attempt to revise the EPL could have far-reaching impacts on China's economic development and environmental protection, which may have global implications ${ }^{52,53}$. Increasing pressures to strengthen the rule of law in China raise the stakes ${ }^{54}$. The National People's Congress (NPC) (the highest legislative body in China) Standing Committee included major revision of the EPL in its 2011 legislative agenda (see supplementary materials (SM)). Proponents for radical revisions (e.g., the Ministry of Environmental Protection (MEP)) opposed other agencies and ministries that favor incremental adjustments. The 2012 draft revision shows the power of the incrementalists: Only the most urgent, feasible, and commonly agreed- upon improvements that require little change of other existing environmental laws have been included $^{55,56}$. Release of the draft revised EPL has triggered a flood of questions, comments, and complaints ${ }^{57,58,59}$ (SM). Debates resounded during the 2012 National Congress of the Communist Party of China (CPC), when top leadership changed and "Ecological Civilization" (restructuring the economy to achieve man-nature, production-consumption harmony) was included in the Constitution of the CPC, with emphasis on scientific and democratic governance under the rule of law ${ }^{60,61}$. Inclusion in the Constitution strengthened the legal and authoritative position of ecological civilization in development planning. Because EPL revision was not approved by the NPC in March 2013, a new round of drafting is in process. The Legislative Affairs Commission of NPC has listed an EPL revision in

\footnotetext{
${ }^{50}$ Organization for Economic Cooperation and Development, Environmental Compliance and Enforcement in China: An Assessment of Current Practices and Ways Forward, OECD (Paris 2006).

${ }^{51}$ C. McElwee, S. Squire \& Dempsey, EnVironmental LaW in China: Mitigating Risk AND ENSURING ComplianCE (New York: Oxford Univ. Press 2011).

${ }^{52}$ T. Wang, Environmental Protection Law Revision: A Collection of Opinions (in Chinese), SOUTHERN WEEKLY, Guangdong, Sep. 14, 2012. Available at http://www.infzm.com/content/80777.

${ }^{53}$ For more information about EPL revisions, see Available at http://www.npc. gov.cn/huiyi/lfzt/hjbhfxzaca/node_19114.htm.

${ }^{54}$ G. He ET AL., ENVIRON. DEV. 325 (2012).

${ }^{55}$ J. Wang, ENVIRON. Protect. 1134 (2011) (in Chinese).

${ }^{56}$ Available at http://www.cenews.com.cn/ztbd1/hbf/ (in Chinese).

${ }^{57}$ T. Wang, Environmental Protection Law Revision: A Collection of Opinions (in Chinese), SOUTHERN WEEKLY, Guangdong, Sep. 14, 2012. Available at http://www.infzm.com/content/80777.

${ }^{58}$ For more information about EPL revisions, see Available at http://www.npc. gov.cn/huiyi/lfzt/hjbhfxzaca/node_19114.htm.

${ }^{59}$ Available at http://www.cenews.com.cn/ztbd1/hbf/ (in Chinese).

${ }^{60}$ Full Text of Constitution of Communist Party of China, revised and adopted at the 18th CPC National Congress on November 14, 2012, Xinhua News, Beijing, 2012. Available at http://news.xinhuanet.com/english/bilingual/2012-11/18/c_131982634.htm.

${ }^{61}$ State Council, Decision on Implementation of Scientific Development and Strengthening on Environmental Protection (in Chinese), (December 3, 2005). Available at http://www.gov.cn/ zwgk/2005-12/13/content_125736.htm.
} 
the 2013 legislation plan. Following major gapes still exist in new law.

In compliance with the Constitution, environmental protection and ecological civilization as national basic policy must be reaffirmed. The EPL should provide a legal basis for key environmental principles: the precautionary and prevention principles, public environmental rights and participation, and environmental justice ${ }^{62,63}$. These are absent or insufficiently stressed in the current draft. A strong legal basis must be provided for independent strategic environmental assessment and performance-based auditing. The current Environmental Impact Assessment (EIA) law only requires EIA of plans or projects not of policies ${ }^{64}$. Although after the fact environmental audits should be conducted on all major public projects and programs by independent auditing institutions, few have been conducted because of limited capacity and knowledge within the National Audit Office and lack of legal backup ${ }^{65}$. Environmental audits should be indispensable parts of decision-making of major governmental investments. EPL revision provides an opportunity to remove obstacles for powerful policy and to plan EIAs and governmental environmental audits crucial for science-based environmental policies. Law enforcement must be improved. Principles for defining, coordinating, and supervising transregional and inter and intra departmental environmental rights, responsibilities, and obligations of governmental and nongovernmental actors need to be specified in the revised EPL. Internal and external evaluation of environmental performance of governmental organizations and officials should become compulsory and transparent ${ }^{66,67}$. Adequate rules for punishment must be set up and enforced to penalize those who violate the law administrators, regulators, and regulated parties alike ${ }^{68}$, e.g., through double punishment (punish the violating company and its owner), a daily penalty for continuous environmental violations, and avoiding low penalties. To align with litigation laws, the revised EPL should adopt public interest litigation and grant any public entity or citizen the right to bring violating

\footnotetext{
${ }^{62}$ J. W. CHANG, U.S.-CHINA LAW REV. 51 (2008).

${ }^{63}$ X. Ma \& Leonard Ortolano, Environmental Regulation in China: Institutions, Enforcement and Compliance, (Lanham, Maryland: Rowman \& Littlefield 2000).

${ }^{64}$ J. Wu, I.-S. Chang, O. Bina, K.-C. LAm \& H. Xu, ENVIRON. ImPaCt AsSess. ReV. 3177 (2011).

${ }^{65}$ G. He et AL., EnViron. Manage. 44579 (2009).

${ }^{66}$ X. Ma \& Leonard Ortolano, Environmental Regulation in China: Institutions, Enforcement and Compliance, (Lanham, Maryland: Rowman \& Littlefield 2000).

${ }^{67}$ World Bank, Strengthening China's Environmental Protection Administrative System: Analysis and Recommendations, No 12323, World BANK OtHer OPERATIONAL Studies (The World Bank 2009). Available at http://EconPapers.repec.org/RePEc:wbk:wboper:12323.

${ }^{68}$ Organization for Economic Cooperation and Development, Environmental Compliance and Enforcement in China: An Assessment of Current Practices and Ways Forward, OECD (Paris 2006).
} 


\section{ENVIRONMENTAL STABILITY STILL IN DANGER963}

administrative departments and other entities to court ${ }^{69,70}$. The revised EPL should shift from regulation to governance, promoting participation of nongovernmental stakeholders and balancing "hard" instruments (e.g., command-and-control) and "soft" (e.g., environmental education and voluntary agreements) ${ }^{71,72,73}$. More transparency and public participation in policy and regulatory processes at all stages, from drafting legislation to enforcement activities, can improve policy effectiveness and address potential inconsistencies. Revision of the EPL can improve the government's legitimacy for promoting ecological civilization by following expert advice, including public suggestions, and empowering environmental authorities for sustainability ${ }^{74}$. It is a unique opportunity for China to be a role model, especially for other emerging economies. Effective environmental governance needed a new law. Now it requires robust implementation mechanisms, accountability regimes and institutional arrangements.

\section{CONCLUSION}

Decades of rapid economic growth have taken their toll on the China' ecology, while disturbingly lenient penalties have indulged excessive environmental pollution. China ravaged by pollution needs to wage a war against it. Economic development paying little heed to green concerns and a huge population has left China a serious headache. This long tug of war indicates that, parts of the government are still more concerned that, environment protection could become an obstacle to economic growth. Threats to public health and sustainable development make the new law more pertinent than ever. Compared to western countries which dealt with some environmental problems decades ago, China is under considerable pressure with synchronized efforts needed to address air, water and soil pollution all at the same time.

Although NGOs file suit against environmental destruction, yet enforcement and litigation costs remain grey areas. The new law imposes heavier punishment on polluters, but will it be enough to repair the damage

\footnotetext{
${ }^{69}$ For more information about EPL revisions, see Available at http://www.npc. gov.cn/huiyi/lfzt/hjbhfxzaca/node_19114.htm.

${ }_{70}$ J. WANG, EnVIRON. Protect. 1134 (2011) (in Chinese).

${ }^{71}$ G. He et al., EnVIRON. Dev. 325 (2012).

${ }^{72}$ A. P. J. Mol \& N. Carter, China's Environmental Governance in Transition, 15(2) ENVIRON. PoLIT. 149-170 (2006).

${ }^{73}$ He, G. Z., A. P. J. Mol \& Y. L. Lu, Trust and Credibility in Governing China's Risk Society, 46(14) ENVIRONMENTAL SCIENCE AND TECHNOLOGY 7442-7443 (2012).

${ }^{74}$ J. Liu, China's Road to Sustainability, 328(5974) SCIENCE 50 (2010).
} 
done by decades of reckless development? For a country mired in pollution amid mounting public anger over a deteriorating environment, strict implementation of the new law is more relevant than ever. Meanwhile, though approval of the environmental law revisions is enough reason to rejoice, it would be simple-minded to believe that, the new law will automatically solve all troubles overnight, since China's ecological problems are the result of decades of reckless pollution. New provisions are helpless in getting local officials to enforce the rules effectively. The success of China's new environmental law will be in its implementation. In China, how a law is enforced is much more important than how it looks on paper. A lack of good legislation is not the cause of China's ecological crisis, but rather a failure by government to prioritize the environment and enforce laws effectively.

The actual implementation of the new law is a key to real change. However, implementation can be problematic. For example, there has been a regulation on environmental information disclosure for several years, yet many local environmental protection bureaus still do not follow the regulation. 